Relations industrielles

Industrial Relations

\title{
Harrisson, Michael I., and Arie Shirom, Organizational Diagnosis and Assessment: Bridging Theory and Practice
}

\section{Laurent Bélanger}

Volume 55, numéro 2, 2000

URI : https://id.erudit.org/iderudit/051319ar

DOI : https://doi.org/10.7202/051319ar

Aller au sommaire du numéro

Éditeur(s)

Département des relations industrielles de l'Université Laval

ISSN

0034-379X (imprimé)

1703-8138 (numérique)

Découvrir la revue

Citer ce compte rendu

Bélanger, L. (2000). Compte rendu de [Harrisson, Michael I., and Arie Shirom, Organizational Diagnosis and Assessment: Bridging Theory and Practice]. Relations industrielles / Industrial Relations, 55(2), 368-370.

https://doi.org/10.7202/051319ar

Tous droits réservés @ C Département des relations industrielles de l'Universite Laval, 2000
Ce document est protégé par la loi sur le droit d'auteur. L’utilisation des services d'Érudit (y compris la reproduction) est assujettie à sa politique d'utilisation que vous pouvez consulter en ligne.

https://apropos.erudit.org/fr/usagers/politique-dutilisation/ 
alors considérablement moins de notes, et la lecture s'en trouverait de beaucoup facilitée.

Cependant, il s'agit somme toute d'un problème bien mineur par rapport à la très grande qualité du fond, à l'originalité du système réglementaire proposé. Ce système, soit dit en passant, fait une place de plus en plus grande à la participation des employés et de leurs représentants. Même les États-Unis, traditionnellement réfractaires à une telle participation, semblent vouloir modifier leurs règlements dans cette direction. Il semble donc y avoir un vent de changement en matière de santé et sécurité au travail : bonne nouvelle pour ceux et celles qui font carrière dans ce domaine!

Michel Pérusse

Université Laval et

Prévention des accidents, Noranda

\section{Organizational Diagnosis and Assessment: Bridging Theory and Practice by Michael I. HARRISSON and Arie SHIROM, Thousand Oaks, Calif.: Sage Publications, 1999, 486 p., ISBN 0-8089-5511-1.}

This book invites planned change or organizational development practitioners and consultants to depart from a specific frame of reference, explicit or not, for which they have acquired skills and to adopt instead what the authors call a "sharp-image diagnosis" framework. This type of diagnosis begins with a broad frame at the outset (the scouting phase of an intervention), in order to get a comprehensive or holistic view of what is going on in the client organization, of the gaps between the actual state and the desired state held by the different stakeholders, and of the sources of these inefficiencies. The diagnosis then moves beyond this opening phase by "zooming-in" on one or more specific features of the organization. For that purpose, a particular conceptual apparatus or model and data-gathering methodology are required, used within the broad framework as a complement to it or as a concomitant way of uncovering specific dimensions and challenges of the client organization.

To develop their new approach, the authors divide their work in five parts, each containing four or five chapters, except the last, which contains the concluding chapter. The first part is devoted to a presentation of the foundations of the diagnostic stage. After discussing different approaches to conducting a diagnosis, the authors then present the well-known open systems framework, describing its components and its interdependencies, as well as the interface between the system and its environment. Here, the authors devote a full chapter to measures for assessing the effectiveness and ineffectiveness of a system. A description of other approaches derived from the open systems frame such as the Six-box model and the Stream Analysis follows along with critical comments on their advantages and limitations. The fifth chapter is a long discussion of organizational politics as they affect the intervention process, more specifically the relationship that develops and that has to be maintained between the consultant and the client organization. To assess the power of the different actors implied in the diagnostic work and the subsequent intervention, the authors develop methods for data gathering, more precisely the force field analysis model.

The second part of the book opens with a discussion of ways of analyzing specific features using a particular model in conjunction with the open systems broad frame of reference. These specific features are called "focal areas". The sixth chapter concerns the assessment of group effectiveness and the factors responsible for it. Here the authors 
use an adaptation of the systems model, one that takes into account not only the factors affecting group effectiveness at the group level, but other factors at the individual and the organizational level. This approach ensures that the assessment of group functioning and performance is not conducted in an organizational vacuum. Organizational design is a second focal area brought to the practitioner or consultant's attention. To assess the adequate structuring of the client organization, the authors propose four different models: open systems, structuro-functionalism, symbolic interpretation, and negotiated order. This takes them into a discussion of the degree of decentralization and the span of divisionalization, in which they refer to the mechanistic or organistic viewpoints as different ways of assessing the fit between the client organization and its environment. Assessing the effectiveness of Human Resource Management activities is the third focal area. For that purpose, the authors prefer the multiple stakeholder approach or what is usually called the multiple constituencies method of evaluating the contribution of an HRM department. To assess the impact of workgroup diversity on emerging or informal behaviour, the authors discuss the benefits and drawback of the symbolic interaction model, which is borrowed from one stream of cultural anthropology. The same approach is used to assess the contribution of a particular organizational culture to organizational performance, which is the topic of Chapter 10. The discussion of cultural gaps or clashes and cultural fits draws on the cultural inventory approach in addition to the interpretative model and other qualitative methods.

The third part of the book deals with different applications of the sharp-image framework in the assessment of an organization's capacity to cope with a turbulent or stable environment across the various organizational life cycles and within a particular life cycle. Chapter 12 focuses on labour relations as an application area. The idea here is to assess the effectiveness or ineffectiveness of a labour relations system and to analyze the bargaining power of the parties involved by testing a particular model called "organizational politics". The use of an open systems framework in conjunction with that model is very convenient since students, scholars and practicians in the field of labour relations are familiar with the system concept, first pioneered in this area by John Dunlop.

Leaving the field of labour relations, the author next examine the process of strategy formation, showing the way to apply the open systems framework to the strategic decision-making process. For those readers, familiar with strategic thinking either in terms of Ansoff's formal process or Mintzberg's emergent process, the parallel between the open systems and strategic management approaches becomes clear. In the same stream of thinking, the authors examine the capacity of an organization to learn and innovate, and demonstrate this capacity by listing the structural and cultural conditions that facilitate organizational learning. The study of macrosystems is another area that the authors explore and, to illustrate their approach, they adapt the sharp-image framework described in the first chapter and apply it to a national health-care system.

The last part of the book, consisting of a final chapter and conclusion, discusses how to bridge the gap between theory and practice. The conditions for using multiple theories, models, or frames are examined, and the importance of the choice between models is emphasized. Is it preferable to use one or more models in a sequence or in a concomitant manner? Is it possible to use one complementary and one conflicting framework at the same time? There are some of the interesting questions discussed in this last chapter.

The book as a whole is a compendium of up-to-date descriptions and 
critical discussions of what is available in the area of planned change or organizational development as far as models, frameworks, and data gathering instruments are concerned. From this angle, the book is worthwhile reading. However, the many good reasons for proposing the idea of the sharp-image framework in the first chapter might have been used to provide a more central theme or a momentum to the book and, by doing so, make more apparent the links between the different parts and chapters. For instance, the chapters dealing with group performance, labour relations and strategic management should have been linked more tightly to the presentation of the open systems model, since these subjects or areas are conveniently dealt with as adaptations of this broad framework and which is also the foundation of the sharp-image diagnosis model. Other particular topics such as organizational culture, organizational politics, workforce diversity should have been dealt with in terms of the concept of multiple frames in sequence or in parallel.

LAURENT BÉLANGER Université Laval

\section{Les acteurs de l'innovation et l'entreprise}

sous la direction de Caroline Lanciano, Marc Maurice, Jean-Jacques

Silvestre et Hiroatsu NoHARA, Montréal-Paris : L'Harmattan, 1998, 272 p., ISBN 2-7384-7184-6.

Cet ouvrage rassemble une douzaine de textes sollicités par le LEST (Laboratoire d'économie et de sociologie du travail) auprès de chercheurs d'horizons divers. Ces contributions - études de cas et analyses à portée plus générale - sont ventilées en trois parties traitant, respectivement, de la « construction des acteurs de l'innovation », de l'action de l'entreprise en tant que « lieu innovant » et de l'«espace d'innovation », notion dans laquelle les auteurs reconnaissent à la fois l'entreprise et son environnement.

Dans l'introduction, les auteurs soulignent d'emblée le caractère paradoxal de l'innovation. Un caractère qui tient moins à cet aspect de « créativité organisée » qu'à cette tendance de l'innovation à entraîner dans sa dynamique propre l'ensemble du système productif. Ce caractère se cristallise notamment autour de ce que les auteurs ont appelé la « fonction technique ». En s'appuyant sur des résultats dégagés par des études comparatives sur la formation, le rôle et la place des ingénieurs dans différents pays, ils font ressortir l'importance analytique de trois notions de base : celle d'« espace de qualification », dégagée et illustrée par la comparaison FranceAllemagne, la notion d' " espace industriel $»$, caractérisant la comparaison France-Japon, ou encore la notion d'《espace d'innovation », à partir de laquelle sera en définitive posée la question centrale, objet de toutes les contributions de l'ouvrage : celle de la «construction sociale » de l'innovation et des processus de cette construction.

Dans la première partie de l'ouvrage les auteurs s'interrogent sur la «professionnalité » des acteurs de l'innovation, notamment à travers les cas des ingénieurs et des chercheurs, et sur sa subordination potentielle aux « spécificités nationales ». Les analyses développées partagent dans l'ensemble une hypothèse, évoquée de plus en plus instamment dans de nombreux travaux de recherche récents - que l'équipe du LEST fait également siennes - qui consiste à considérer l'émergence de nouvelles formes d'innovation dans les entreprises comme une « nouvelle rationalité du système productif $»$. Un constat commun semble émerger, vers lequel convergent la plupart des contributions 